\title{
Hercules Humphreys: celebrity centenarian?
}

\author{
Trevor J. Cooper
}

Abstract: A portrait of Hercules Humphreys, made in his alleged 102nd year, was the attraction to finding out more. The essential challenge, described in this article, was to confirm or disprove his claim to be 101 when he died. It became evident that Hercules'

Received: 18 February 2019

Accepted: 30 September 2019

Additional information is available at the end of the article.

KEYWORDS: longevity; centenarians; popular interest; paternity; portraits story reflected a popular interest in people who lived to a great age. Whatever the truth of his claim, the general fascination with people of supposed great age generated portraits of people such as Hercules, often people of the lower and middling sorts of society, rather than the wealthy and powerful. This enables us to see images of people who, but for their age, would not have bequeathed their likenesses to posterity.

\section{Introduction}

I knew that Hercules was an ancestor before I unexpectedly located the portrait (Figure 1) in 1980 while researching Victorian church restoration in Oxfordshire. I had consulted the Bodleian Library's topographical collections in Oxford for pictures of churches before they were 'restored' by the Victorians. This instantly made Hercules a 'person of interest'. I knew he was supposed to be aged 101 from his burial record, but there was no obvious baptism record to support this. The portrait was engraved to mark Hercules being in his 102nd year, which lent some credence to the claim, and necessitated further research to test its veracity. Pursuing this to find some evidence to support this unusual age revealed something more than what I had taken to be a serendipitous find of his portrait. It became evident that this portrait was an example of popular interest in people of great age. The portrait of Hercules was not unique or a curiosity, but part of a wider interest in this phenomenon.

Hercules Humphreys (1699-1800) probably lived in three separate centuries: the seventeenth, eighteenth and nineteenth. He ostensibly lived during the reigns of William III, Anne, and George I, II, and III. There is some interesting surviving evidence for Hercules the person, but we don't know much about him even so. What we do know leaves many questions: did he actually live to be 101 ? Who was his father? Who were his children? These questions also form the substance of what people wanted to know at the time.

\section{Hercules: who was he?}

Hercules was a cordwainer ${ }^{1}$ by trade, i.e., a maker of fine footwear and not a repairer, a cobbler. He was also a victualler, meaning a shopkeeper or innkeeper, a purveyor of food, spirits and supplies of all kinds; effectively he ran a general store for most needs. ${ }^{2}$ He was also a brewer and farmer at various times: there is a suggestion that he owned a malthouse and associated brewery in Newland Street, Eynsham from $1743 .^{3}$ Hercules seems to have held two farms, some 40 acres at Freeland near Eynsham and 10 acres at Hailey, near Witney, Oxon. ${ }^{4}$ He was clearly at the centre of a number of business interests, which would not have been uncommon at the time.

In 1773 Hercules borrowed $£ 160$ from an investor of Eynsham, Oxfordshire and issued a bond to repay the loan with interest. The investor was one 'Thomas Berry of Ensham labourer', whose loan appeared to have been repaid in 1785. There was also another business transaction and loan between Hercules and one James Wastie of Cowley (Oxford) which was entered into an account book in 1781. Unfortunately, these records do not seem to have survived. I only know about them because Hercules was cited by $E$. L. Jones ${ }^{5}$ as one of several examples of how businessmen in the industrial revolution found investors from among their own class, there being no reliable banking system for holding savings or providing loans. Correspondence with E. L. Jones ${ }^{6}$ revealed that he saw these documents and made notes for his research in the 1960s and that they were the property of his landlady, Mrs Charles Pimm, when he was in 'digs' at Eynsham while studying at Oxford. (Apparently, they were offered to Oxfordshire Record Office, but were declined because of their poor condition.) 


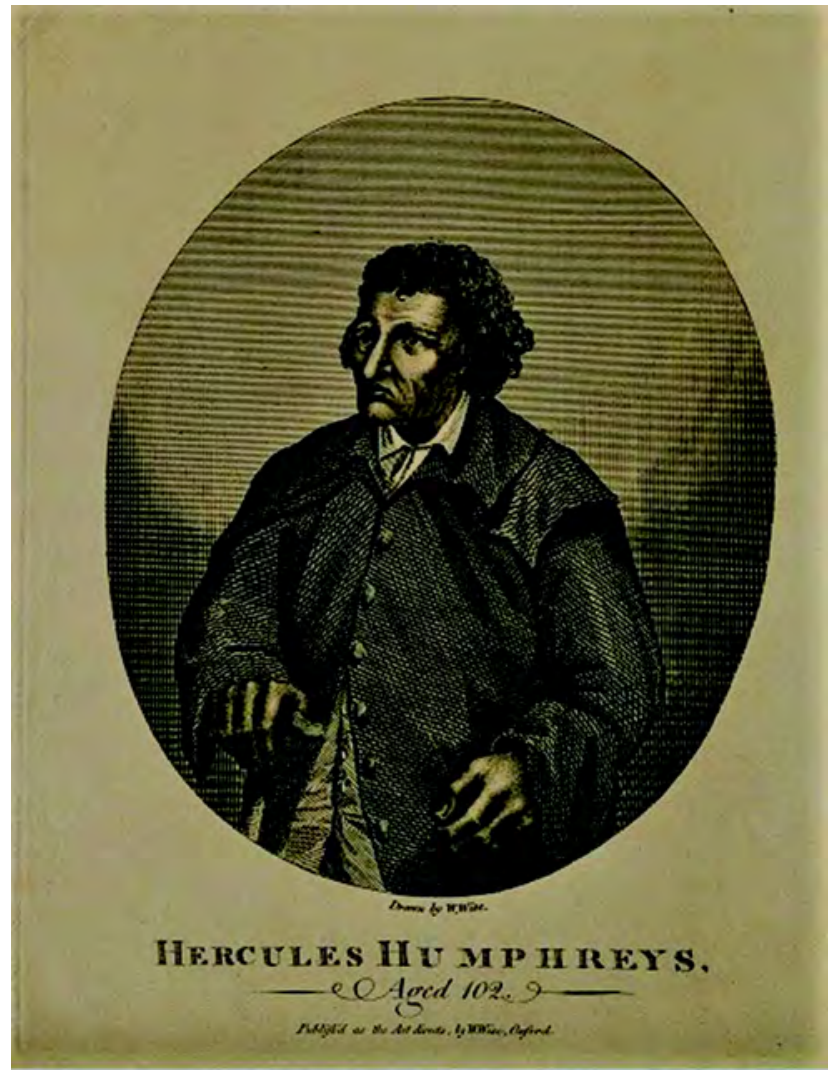

Figure 1. Hercules Humphreys. Engraving by W. Wise, c.1800. From the author's collection.

\section{The interest in centenarians}

Finding this portrait gave me a long-lasting interest in Hercules. I purchased a high-quality photograph of the image from the Bodleian at the time, which I had framed. I was later able to buy an original at auction. It provided motivation to find out more about him, as it is unusual to have a portrait of a common man of this period.

The first portrait I found is in the collection of historical notes, drawings, engravings and portraits of 'local worthies' assembled by Henry Hinton (1749-1816), an Oxford ironmonger and James Hunt (1795-1857), an Oxford chemist. This collection was strangely (and coincidentally) purchased in 1819 and 1820 from James Hunt by Sir Thomas Phillipps, 1st Baronet (1792-1872), an antiquarian collector of rare and unusual books, documents and pictures whose collection is otherwise with the Grolier Club in New York where there is another copy of Hercules' portrait. This part of the collection, which is essentially a scrapbook, was purchased by the Bodleian Library in 1979 from a third party, Sir Anthony Wagner, KCB, KCVO, FSA (1908-1995), who had an interesting career as a genealogist.7

Much of what is known about Hercules is associated with the portrait and his great age at that time. The engraving of Hercules Humphreys was drawn before he died at the age of 101 in September 1800 by W. Wise (who may have been the William Wise born in Eynsham in 1737). ${ }^{8}$ It shows an elderly man wearing an outdoor caped overcoat, over a waistcoat and shirt. He holds a walking cane and his hands are very prominent, and look osteo-arthritic as would be expected of a man of his great age. He appears to be bald and wearing a wig and to have lost his teeth. There are a number of copies of this portrait available in various collections. The most interesting is at the Wellcome Collection, where it is one of a number of portraits of people who have exceeded the centenarian age, some thirty-nine in total. There was also a copy of Hercules' portrait referred to in the collection assembled by the Rev. Daniel Lyons, AM, FRS, FSA, chaplain to the Earl of Oxford, in which he had collected twenty-two portraits of centenarians. ${ }^{9}$ There is an overlap between the two collections. The Lyons collection was broken up and sold at the time the article was written in 1915. There are no images contained in the article, just descriptions of the lives of the centenarians.

Exceptional age was a popular curiosity conferring what we would consider 'celebrity status'. There appears to have been a lot of interest in such people of great age during the seventeenth, eighteenth and nineteenth century. Rylands and Songhurst, describing the collection of the Rev. Daniel Lyons, opened their article with, 'At the present time (1915) one hears very few instances of centenarians and the announcement 
of the existence or the death of one usually arouses a considerable amount of interest'. ${ }^{10}$ The two authors were freemasons writing for their masonic lodge; they recall a 'scarce work' which they commend to their masonic readers. Long Livers: a Curious History of Such Persons of Both Sexes who Have Liv'd Several Ages, and Grown Young Again: with the Rare Secret of Rejevenescency of Arnoldus de Villa Nova, published (posthumously) in 1722, was written by Eugenius Philalethes, also known as Thomas Vaughan (1621-1666). ${ }^{11}$ Vaughan was a philosopher, alchemist, and natural magician who had an interest in people who lived beyond 100 years. The book was dedicated to the 'Freemasons of Great Britain and Ireland' and outlines individuals who had lived this long, seeking to refute the biblical notion of man's allotted lifespan of threescore years and ten. It also recommends various lifestyle changes (temperance being one). It emphasises the importance of having a good constitution through this, and provides recipes for potions which can be taken to assist with longevity. It is concerned not only with people living long lives, but growing younger as they do so, a notion called 'rejuvenescency', or 'rejuvenescence'. This was achieved through lifestyle and alchemy; the taking of potions such as the 'universal medicine' derived from the elusive 'philosophers' stone'. It is a strange pseudo-scholarly book which shows the level of interest in longevity, and a belief that there is perhaps a secret to it.

Indeed, if you google today for centenarians, it is evident that the interest is still there. There is much interest in whether there are secrets to such longevity. We all know that the late Elizabeth, the Queen Mother, lived to be 101. There is a fascination with why the people of Okinawa, Japan, Genoa and Sardinia, Italy have a high proportion of centenarians among their populations. There is often some emphasis on a lifestyle contributing to longevity, for instance the adage 'eat until you are $80 \%$ full instead of gorging'. In Italy, a diet of fresh vegetables, fish, pesto, wine and cheese are highlighted. This is just the sort of thing people wanted to know about Hercules and his fellow centenarians.

In the seventeenth, eighteenth and nineteenth centuries average life expectancy was far short of the biblical ('The days of our years are threescore years and ten; and if by reason of strength they be fourscore years, yet is their strength labour and sorrow; for it is soon cut off, and we fly away'). ${ }^{12}$ People at the time would have been very well aware of legendary biblical figures who lived to great age. Methuselah lived to be $969 .{ }^{13}$ His father Enoch became his father at the age of 65, had further children, and lived to be 365 as he 'walked with God'. Methuselah at the age of 187 became the father of Lamech, who allegedly lived to be 182 and was the father of Noah, and had further sons and daughters.

People who were used to high infant mortality, people dying in their youth and childbirth or just not achieving the full allotted 'threescore years and ten' were very interested in those exceptional people who lived beyond their own experience, and curious about how and why they had lived so long. They were also interested in their on-going fertility in the sense of how many children they had and at what age and, poignantly, whether they still had their mental faculties. Did these 'exceptional people' have fathers or children who lived to a similar great age as an explanation for the phenomenon?

It was noted that one Agnes Milburne 'recently deceased' in 1743, aged 106, had 29 sons and one daughter. A Mary Prescott who died aged 105 in 1765 had 37 children, 'most of whom are still living'. ${ }^{14}$ There was Thomas Parr, known as 'Old Parr' (1483-1635), who supposedly lived to be 152; the main interest was in his descendants. It is reported that his son, 'Young Parr', lived to be 113, his son lived to be 109, and his son lived to be $124 .^{15}$ This confirmed the readers' expectations of fertility and heredity.

Beyond the believed facts of age, lifestyle was of interest. In 1782, John Wilson of Worlingworth, Suffolk, died aged 116. 'Having supped for the last 40 years of his life on roasted turnips is thought to have contributed to (his) long life'. ${ }^{16}$ Again, this confirmed the readers' expectations, and suggested a secret in a peculiar diet. There is no evidence, however, for the existence of John Wilson: it is possible he never existed but provided a popular item of news.

There is a pen and ink drawing of the head of Henry Jenkins in the Wellcome Collection (Figure 2). Jenkins supposedly died, aged 169, in 1670. An autopsy was probably conducted to see if anything of use could be learned. Figure 3 is an etching of the same man, also in the Wellcome Collection.

There was even a form of competitiveness in great age. Rylands and Songhurst say:

\footnotetext{
There seems to have been a rival to 'Old Parr' (Thomas Parr aged 152) in the seventeenth century, as we are told that the following inscription was copied from a tombstone in Carben churchyard near Cardiff: 'heare lieth the body of William Edwds of the Cairey who departed this life on the $24^{\text {th }}$ February 1668 aetatis $168^{\prime} .^{17}$
}

The portraits of all of these centenarians were cheap prints for populist consumption. The media varies. Hercules was an engraving; all the others in these collections are similar: engravings, wood-cuts, mezzotints, hand-coloured prints, stipple engravings, etchings, coloured etchings, and lithographs. Only two are the oil paintings reserved for the important and wealthy, which these subjects were not: that of 'Old Parr', and Sarah Lyon, as is shown below. It is interesting to break down the thirty-nine portraits held by the Wellcome Collection using a 


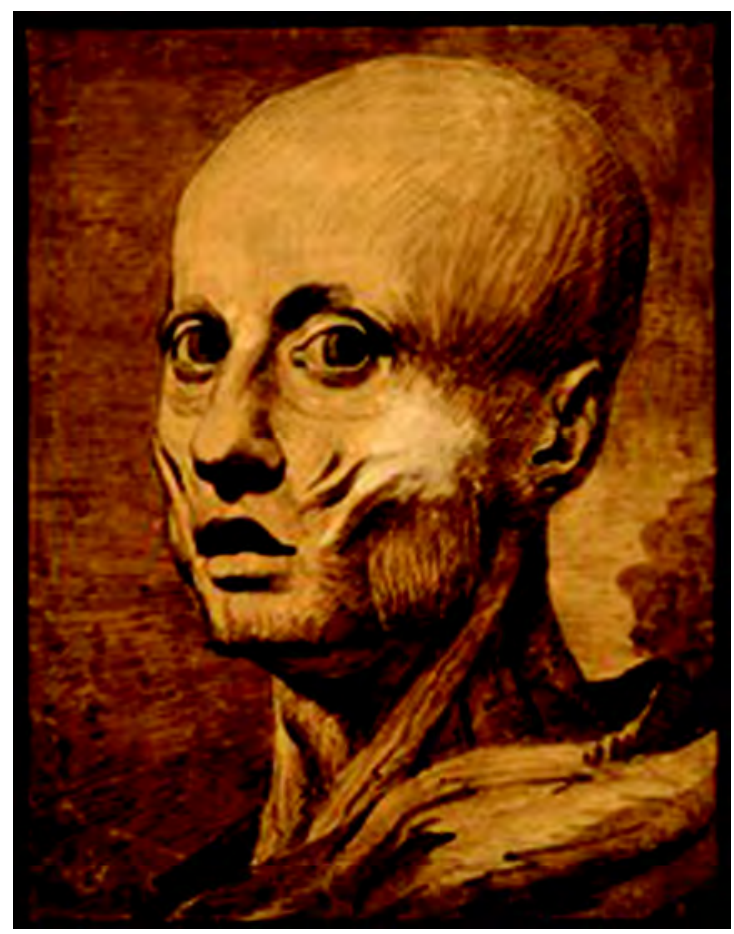

Figure 2. Anatomical study of the head of Henry Jenkins, aged 169. Pen and ink drawing. Wellcome Collection. CC BY.



Figure 3. Henry Jenkins, aged 169. Etching by T. Worlidge, 1752, after R. Walker. Wellcome Collection. CC BY. 
definition put forward by Petersen and Jeune. ${ }^{18}$ This distinguishes between centenarians aged up to 110 years, and 'supercentenarians' over 110 years. The Wellcome Collection has twenty-two centenarians in the former category and seventeen in the latter.

There was, of course, scepticism about these claims to great age. Petersen and Jeune refer to William John Thoms' study, published in1873. William John Thoms, FSA (1803-1885) was a writer, folklorist, and antiquary who made a career of debunking longevity claims and laid down rules for validating such claims. His major work in this area was Human Longevity: its Fact and its Fictions, published in $1873 .{ }^{19}$ In itself, Thoms' book is testimony to the on-going interest in centenarians. He made a close study of three famous British long-livers, among a number of others. ${ }^{20}$ He looked at Henry Jenkins (age 169), Thomas Parr ('Old Parr') (age 152) and Katherine, Countess of Desmond (age 148), who were the three alleged longest British livers, in which he concluded that there was little substantial evidence, and that their claims rested on their alleged memories. It is interesting that Rylands and Songhurst also noted of Desmond that, 'Of this great age, 106 years are satisfactorily accounted for ... the remaining 42 seem quite probable'. ${ }^{21}$ There is an element of this about Hercules, whose claimed memories were very likely those of his older wife, who was deceased.

Peterson and Jeune's work is an investigation of the collection of Bolle Willum Luxdorph (1716-1788), who was a Danish civil servant and scholar who took an academic interest in long-livers. He made a study and a collection which formed a manuscript, 'catalogus longaevorum' of information on centenarians, and icones longaevorum, the accompanying images he had acquired to illustrate his text. Luxdorph was part of the popular interest in centenarians and he gathered information from all over Europe. He tried to investigate the truth of some claims and also took at face value many others. The works contain information on several hundred persons. These do not include Hercules Humphries who died after Luxdorph.

Thoms shows the celebrity status of these people irrespective of the truth of their age. He says that Thomas Parr was taken (in a litter or wagon) from Shropshire to London by Thomas Howard, the Earl of Arundel, to meet King Charles I in 1635. Thomas was treated well, was lodged in the Strand, and crowds came to see him. His portrait was painted by the great Sir Peter Paul Rubens (1577-1640). There is a copy of the original work in the National Portrait Gallery in London, showing him with dark brown eyes, and white shaggy eyebrows, moustache and whiskers (Figure 4). Rubens could have been available to do this portrait as he was in London working for the king on the ceiling of the Banqueting House at the Palace of Whitehall.

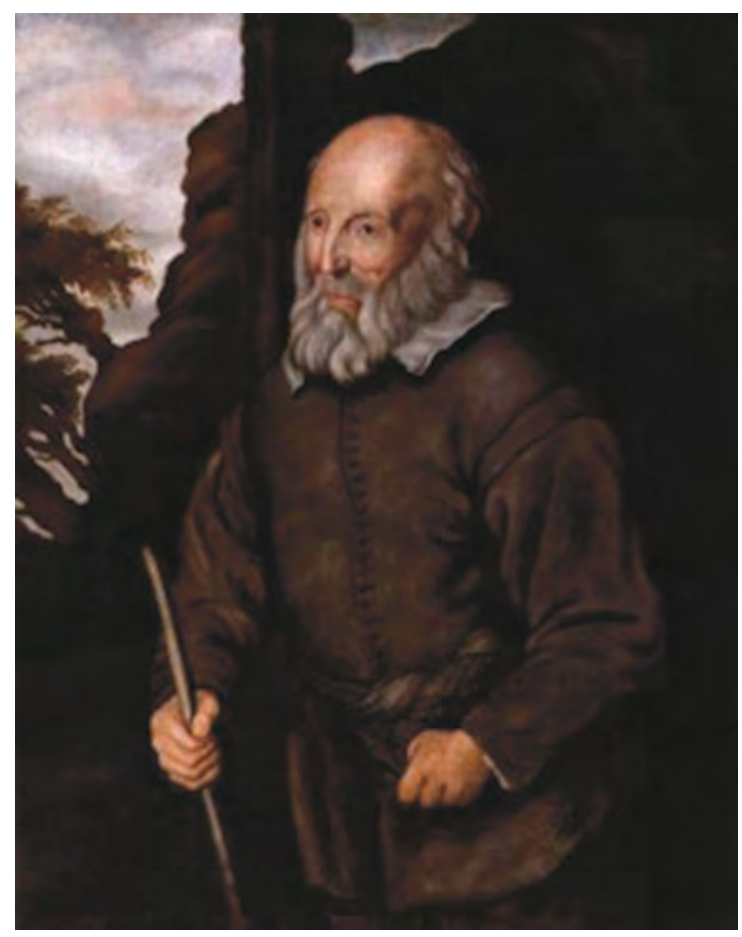

Figure 4. Thomas Parr after Unknown artist, oil on canvas, based on a work of 1635. NPG 385. ๑ National Portrait Gallery, London. 
Some of the more widely available engravings were made from the Rubens' painting's image; others are based on a different image. It is interesting in terms of Parr's celebrity status how many engravings were made: the Wellcome Collection holds eight different versions. It is also useful to note that the earliest was made in 1635 and the latest in 1807, which shows a long abiding interest in the man and his great age. One print was made in the image of a medal, or the obverse of a coin, another was made with symbols relating to mortality in the border; no doubt for the edification of the viewer (Figures 5, 6 and 7).

A popular pamphlet was published in 1635 on the occasion of Parr's visit to London. ${ }^{22}$ It is a long poem which recounts his life, and how he was at that time: blind, having lost his teeth, but able to walk if held up, and enjoying his food and a glass of sherry. It covers the usual areas of interest in those of great age, in that his senses 'had not shrunk', and that he was a 'living mortal monument'. It refers a lot to his extensive memory of past events. It eulogises his father and grandfather for being long-livers also, and recounts their memories back to Edward the Confessor and William the Conqueror. His long life is attributed to a simple lifestyle: 'This man ne'er fed on dear compounded dishes, of metamorphos'd beasts, fruits, fowls and fishes, the earth, the air, the boundless Ocean, were never rak'd, forag'd for this man'. Thoms investigated Parr closely, and concluded that nothing could be verified to substantiate Parr's age. ${ }^{23}$

Parr died in London, and his body was taken for an autopsy, conducted by Dr William Harvey (1578-1657), who was famous for his discovery of blood circulation. Harvey did not discount the possibility that Parr was, in fact, 152. It seems that Parr's long life was due to a diet of green cheese, onions, coarse bread, buttermilk or mild ale (cider on special occasions) and no smoking, which kept Thomas healthy. His recipe for long life was reputed to be: 'Keep your head cool by temperance and your feet warm by exercise. Rise early, go soon to bed, and if you want to grow fat (prosperous) keep your eyes open and your mouth shut'. ${ }^{24}$ It seems that the opportunity of richer food and wine, together with the general pollution in London, was considered to be the cause of death.

By order of the king, Parr was buried in Westminster Abbey, where an inscription was placed which listed the ten kings and queens in whose reigns he had supposedly lived:

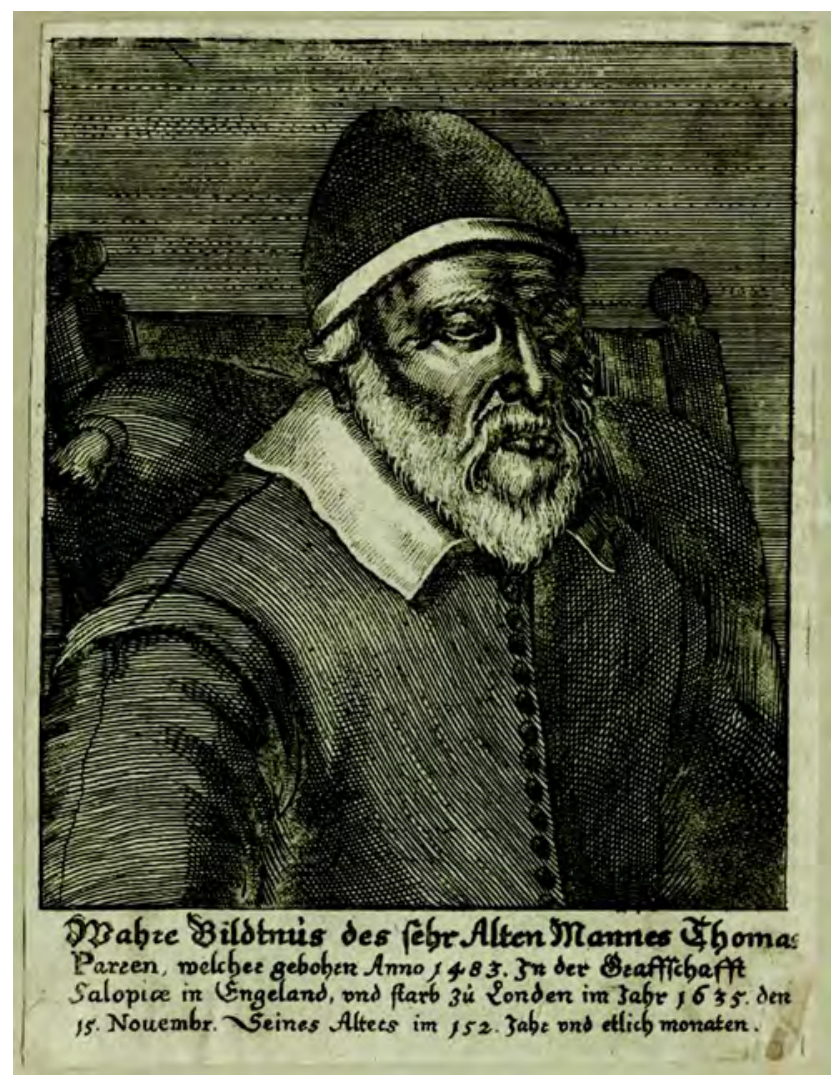

Figure 5. Thomas Parr after Unknown artist, etching, mid 17th century. NPG D28497. ๑ National Portrait Gallery, London. 


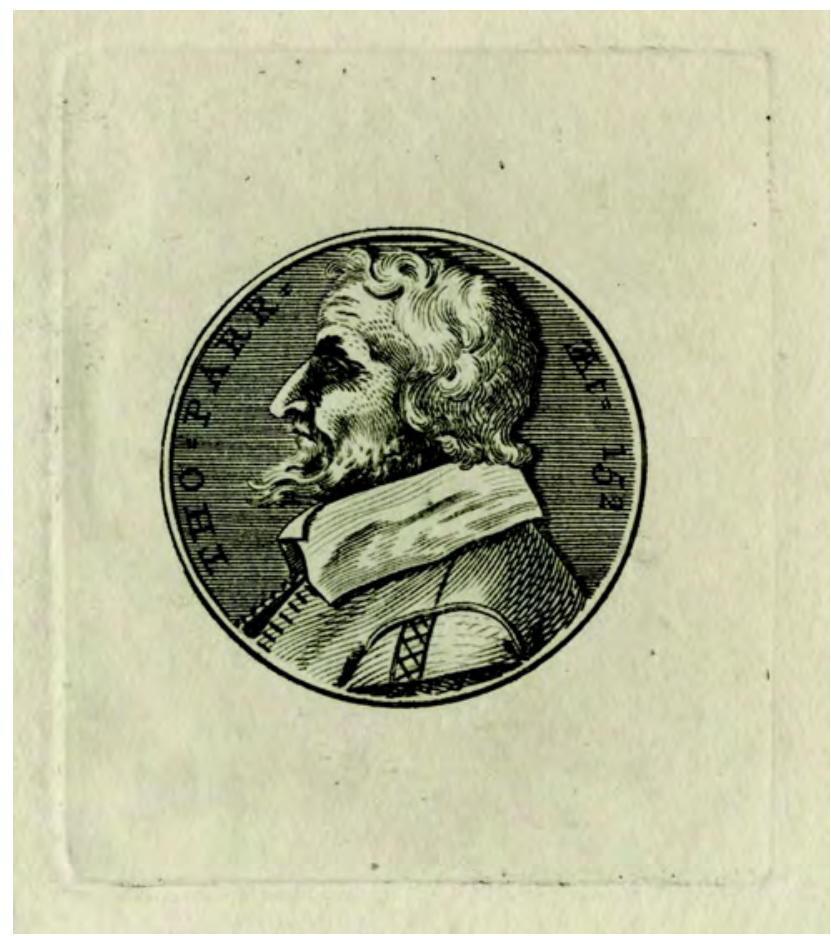

Figure 6. Thomas Parr after Unknown artist, line engraving, 18th century. NPG D28496. $\odot$ National Portrait Gallery, London.

THO: PARR OF YE COUNTY OF SALLOP. BORNE IN AD: 1483. HE LIVED IN YE REIGNES OF TEN PRINCES VIZ: K.EDW.4. K.ED.5. K.RICH.3.

K.HEN.7. K.HEN.8. K.EDW.6. Q.MA. Q.ELIZ. K.JA. \& K.CHARLES. AGED 152 YEARES. \& WAS BURYED HERE NOVEMB. 15. $1635 .{ }^{25}$

This was renovated in the late nineteenth century, which shows the abiding interest in centenarians. It is still there to be seen.

In Suffolk, Sarah Lyon of St Peter's, Ipswich, who lived into her 105th year (1703-1807) was painted by John Constable (1776-1837) in 1804 (Figure 8). (Sarah Lyon is also referred to as Lyons in many texts. However, Rubinstein and Jolles suggest that Lyon is her correct name. ${ }^{26}$ ) Constable was not known for painting portraits, although a hundred are known. It is possible his family encouraged this in the hope that he would become a fashionable portrait painter and make a good living: landscape painting was considered an inferior genre. ${ }^{27}$ The painting is another example of the celebrity status of centenarians, as subsequent engravings were probably made from the painting for wider circulation (Figure 9).

The engraving by R. H. Roe is a reverse image of the Constable painting, with a slight change in the position of the hands. This could be because the engraving claims to be 'after a painting by Walter Stephens Lethbridge'. This is important because Lethbridge (1771-1831) was a successful and fashionable painter of miniatures of the notable people of the time (to be worn as jewellery and given as tokens of love, regard or remembrance). He ran a thriving practice in the Strand, London. It is possible that Lethbridge copied the Constable painting, and produced a miniature or miniatures, but this is not known. It is likely that the engraving was indeed copied from this in 1822 by R. H. Roe. Either way, the importance of this is the involvement of a fashionable portraitist in the process, as well as the up and coming painter Constable.

The usual level of interest was shown in Sarah Lyon. It was reported that, when she died, she had 'possession of all her faculties'. It was also claimed that she had two children. ${ }^{28}$ The sources vary on this and it is likely she only had one child: her son, Isaac, who himself died in 1818 aged 87 (thus born in 1731), and may also have been painted by Constable in 1803. ${ }^{29}$ This does not demonstrate the expected level of fecundity which was of much curiosity. (My ancestor, Hercules, was credited with having a youngest child aged seven, which in reality was his great-grandchild, but it made a better story to suggest that he was still active.) On the positive side, Sarah's health was good. It was claimed that she had not suffered any 'long sickness' in forty years. Her diet 'consisted principally of soups and vegetables, with a large portion of fat, 




Figure 7. Thomas Parr after Unknown artist, woodcut, mid to late 17th century. NPG D28499. ๑ National Portrait Gallery, London.

or butter (of which she was very fond), mixed with them, and occasionally fish. For supper she took only a small piece of bread and butter, and half a pint of porter'. It was also noted that, while she retained her faculties, she suffered a 'paralytic stroke' two years before she died, when 'she was deprived of the use of her limbs'.

Hercules the centenarian

Hercules was held to be a centenarian, and the interest in him mirrors the general fascination with other centenarians. The portrait and what was recorded about him conform to this popular interest. The engraving of Hercules shown above was printed as a souvenir for visitors and tourists. Wise says that it was drawn about a week before he died; however, this may be to sensationalise the portrait in terms of proximity to mortality. The overseers' accounts for Eynsham contain an interesting entry for May 1800: 'for shaving Hercules, Jas Smith \& Saulbury 5/-'. This suggests that the parish paid for a shave and tidy-up, perhaps ready for the portrait. Hercules is clean-shaven in the portrait. ${ }^{31}$ He did not die until September, ${ }^{32}$ some months after the shave. There is no evidence that Hercules was supported by parish relief; it is likely that the parish paid for the shave for the portrait because he was well known and the parish was content to have a tourist attraction in the town. It seems that portraits for other centenarians were sold for 5/- each, which was not a small sum. An example was a portrait of Elizabeth Alexander, aged 106, 'supposed to be the oldest woman now living in England' in 1808. Her granddaughter was living with her in Tottenham, London and was selling souvenirs and a print which had a dedication, 'Pray remember the Poor'. ${ }^{33}$

The portrait of Hercules is accompanied by a printed context-setting citation, which covers the usual areas of interest, revealing what people wanted to know about these exceptional people in terms of their fertility, physical and mental fitness (note that Eynsham is a large village five miles north-west of Oxford, which by the standards of the time would be readily within walking distance): 


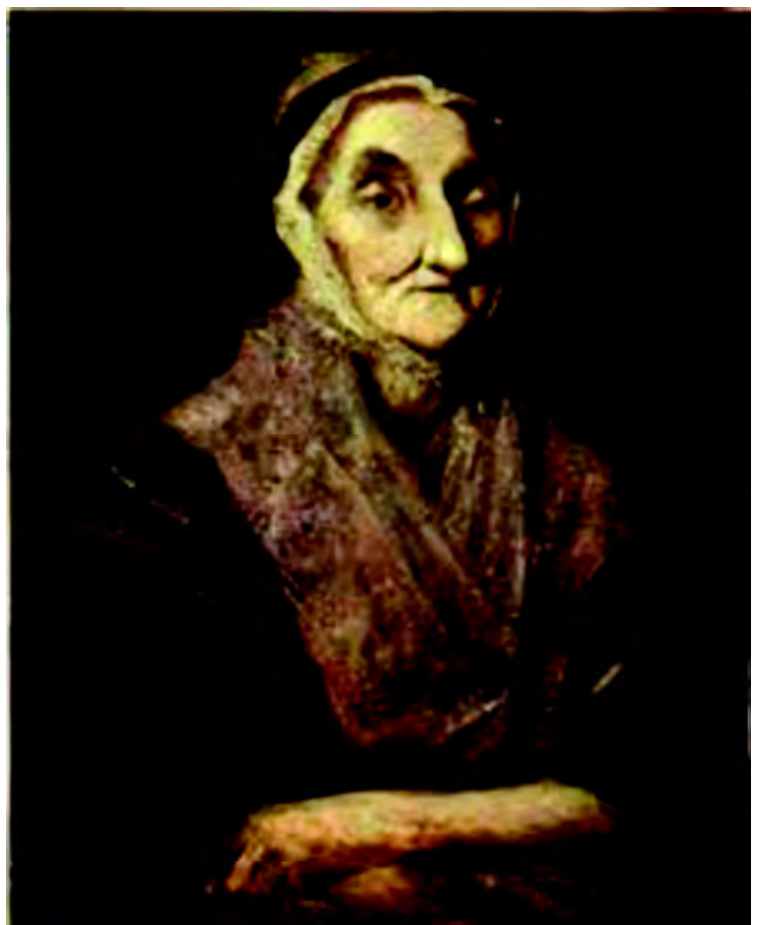

Figure 8. Sarah Lyon by John Constable. Skirball Cultural Centre, Los Angeles, California, USA.

\begin{abstract}
This man was singular exception to the common course of human decay, he had nearly attained the great age of 102 years, in the full possession of his faculties, his memory enabled him to give evidence in a trial at Oxford Assizes in the $101^{\text {st }}$ year of his age, and his strength to walk from Ensham to Oxford for that purpose, and return on the same day. He had been a resident at Eynsham for nearly fourscore years, and was always considered as an old man within the earliest recollection of the oldest inhabitant there. He perfectly remembered the ancient abbey gates, the death of Queen Anne, the coronation of George I. He sat for this portrait in perfect health and spirits about a week before his decease, which happened at Ensham, Sept 201800 . He has left several children, the eldest upwards of 70 and the youngest under 10 years of age. ${ }^{34}$
\end{abstract}

(The last trial Hercules attended, mentioned in the accompanying text to the portrait, would have been the one at the Epiphany Quarter Sessions in 1799. The Abbey Gatehouse was demolished in 1706. The death of Queen Anne and coronation of George I were both in 1714.) The portrait is also accompanied by handwritten notes of a conversation with Hercules by a visitor, Henry Hinton, who purchased a copy of the engraving: 'At the same time I sold him some awls and a knife to mend his shoes with. He told me that he should walk to London and carry a furze of faggots for which he was to have a guinea. ${ }^{35}$ It doesn't make a lot of sense, but Hercules was maybe showing off in the sense of still being able to mend shoes, and think of walking to London, which may have been a wager.

Hercules was clearly well known enough to merit an entry in the Gentleman's Magazine in 1800 in the section called 'Obituary, with Anecdotes, of Remarkable Persons':

At Ensham, co. Oxford, in his 102d year, Hercules Humphreys. He retained the full use of his faculties to the last, and was subpoenaed as an evidence on a trial at Oxford in his 101st year. Of his surviving children, the eldest is 73 , and the youngest only 7 years old. ${ }^{36}$

His death was also reported in several regional newspapers with much the same brief copy, which demonstrates the widespread interest in great age and these people's mental faculties, continuing good health and fertility. The newspaper reports of the death of Hercules covered all of the qualities expected of centenarians by the public. The Hull Packet noted Hercules' death but featured it within a list of royal, noble and otherwise notable people. ${ }^{37}$ In particular, it included two other centenarians who had recently died. There was an Ambrose Bennett, aged 106 and 10 months, whom it claimed had been a serving soldier for 'near 60 years' and fought in battles in the reigns of Queen Anne, George II and George III: that was evidence of remarkable fitness for the readers. There was also George Jackson, whom it was claimed was baptised in November 1699 and died in October 1800, which are the same years claimed for Hercules. Interestingly, the paper goes on to make a pertinent point: 'So that had he survived three months and three days longer he would have lived in three centuries'. It does not say the same about Hercules, but the chronological point is a good one in that there never was a year zero in the calendar, so the commencement of the 




Figure 9. Sarah Lyon, aged 104. Line engraving by R. H. Roe, 1822 after W. S. Lethbridge. Wellcome Collection. CC BY.

nineteenth century was strictly 1801. (This was, of course, true of the recent millennium celebrations, which should have taken place in 2001 and not 2000, but the popular understanding and common usage is otherwise.) It is interesting that the paper chose to present this technical information, perhaps in the sense of 'so nearly there but not quite', for its readers' edification. Neither of these two centenarians are mentioned in either of the collections considered here.

\section{Hercules: was he 101?}

The curate of Eynsham, Thomas Symonds, administered the last rites to Hercules Humphreys on 14 September 1800 and conducted the burial service. In 1800 the vicar of Eynsham was Thomas Nash, recently appointed rector of Salford, Oxon, who then seems to have left the affairs of Eynsham in the hands of a newly appointed curate, Thomas Symonds.

Thomas Nash, vicar from 1767 to 1826, was resident at first but from 1774 lived in Gloucestershire or at Salford, one of his several livings. In the 1790s he paid Eynsham's curate only $£ 25$ for 'double duty'. Continuity was provided by long-standing curates such as Robert Davis (c.1775-84) and Thomas Symonds (1773-1845), who first served Eynsham as a locum in 1796 and became curate himself in 1797. He married Nash's daughter, Frances, and succeeded to the vicarage in 1826. Nash raised his salary to $£ 60$ in 1804 but Symonds paid rent for the vicarage house and his fees; having spent large sums on the house because he was promised the advowson, he later complained of being misled into serving a large cure for half the normal salary. He made ends meet by running a private school for gentlemen's sons at the vicarage. He was a diligent and popular pastor, remembered as founder of the Sunday school and a friend of the poor; he was also an enthusiastic antiquarian, whose compendious collections on Oxfordshire were never published. ${ }^{38}$

Symonds entered into the burial record Hercules' great age, 'aetat 101 '. He also made notes of the conversation with Hercules and his family in a notebook with soft marbled covers: 
Hercules Humphries was buried at Ensham Sep. 22, 1800, ${ }^{39}$ in his 102 year. He said he could remember the Abbey Gate House. On Sunday Sep 14 th 1800 I administered the Sacrament to him. His Daughter was present \& also received the Sacrament - she was then in her 71 st year. A younger Daughter was present Aged 13. They both assured me that his Father was 107 years old at the time of his Decease. According to the Register of Burford he was baptized June 25 1699. Thos. Symonds. ${ }^{40}$

Did Hercules really live to be 101 ? This is a key question, given that we do not have a firm date of baptism. Symonds' testimony is the only hard evidence available for Hercules' baptism. Symonds states that he has seen the baptism entry in the Burford registers. There is no extant baptismal record in the registers or the Bishop's Transcripts for either Burford or Eynsham. However, there is uncertainty about his birth and therefore his parentage. There was a Hercules Humphreys baptised at Burford on 4 July 1712, son of John Humphreys. It may be that Hercules was, in fact, born in 1712 which would make him 88 rather than 101 in 1800.

It is possible that Hercules was aged 101 in 1800 and had been born in 1699 as Symonds says, but whatever record Symonds saw has not survived. Symonds was an enthusiastic antiquary and would not be likely to write down unsubstantiated information. He seems to have seen, and cites, a specific baptismal date with Burford as the location; importantly, he is not citing a birthdate he has been told, which might be more commonly expected, but a baptism date he says he has seen. This evidence supports the fact that Hercules was baptised in 1699 at Burford. Symonds was also so convinced of the authenticity of Hercules' age that he recorded it in the registers, and he did this for all burials thereafter. This practice in itself is another example of the interest in people of great age.

It is possible that the entry seen by Symonds was a loose piece of paper or page, filed in the parish register in the relevant year as an addendum. These records were not necessarily updated on the day of events, but brought up to date by the clerk or curate at a later time. We often get frustrating gaps in evidence because of this. (A few years ago, while researching another family, I could not locate a baptism for someone I knew to have been born in 1790 in that village. There was no record in any transcription. On consulting the original registers, I found a small piece of paper inserted in the register which had clearly been used as a bookmark, with the searched-for person's name, parents, and baptism date. ${ }^{41}$ ) It is possible that Hercules' baptism was a similar addendum which has subsequently been lost: it is not conclusive proof, but is an example of what Symonds may have seen.

There remain two possibilities for Hercules' birth; Symonds' cited baptism for Hercules of 25 June 1699, or the extant entry in the Burford registers of 4 July 1712. For the first, the only evidence is Symonds' testimony, which could be reliable given his interest in history; the second is the written evidence of an entry in the registers. Which is the stronger?

Hercules married Sarah Hobbs at Eynsham on 1 April 1733, described as 'Hercules Humphris de Burford et Sarah Hobbs'. ${ }^{42}$ Hercules born in either 1699 or 1712 would be of the right age for that marriage, which does not help to distinguish them. Sarah was born at Eynsham in 1697. She was therefore older than Hercules of 1699 or 1712. It is possible that in either case, Hercules' recollections were possibly more his wife's than his own. The testimony with the portrait says 'He had been a resident at Ensham for nearly fourscore years, and was always considered as an old man within the earliest recollection of the oldest inhabitant there. He perfectly remembered the ancient Abbey Gatehouse, the death of Queen Anne, the coronation of George I'.43 Given that the Abbey Gatehouse was demolished in 1706, it is very likely that Hercules borrowed this memory, perhaps from his wife. However, by 1800 , no one would be alive to challenge his longevity and memory, whether he was 88 or 101.

\section{Paternity: who was Hercules' father?}

In either case, the issue then is the question of his parentage. It is unfortunate that Symonds did not give the name of Hercules' long-lived father. For both of the possible births of Hercules, we can identify the family and two strong candidates for parentage. For the 1712 Hercules, it is John Humphreys, born in 1688 at Burford, to another John Humphreys (who is referred to as junior because his father was also called John). There are therefore three generations of John Humphreys', all father and son: I shall refer to them as John I (died 1692), John II (born 1661) and John III (born 1688). John III is too young to be the father if 1699 is the birth year for Hercules, but the right age for the 1712 baptism. For the 1699 Hercules the likely candidate is John II, who was born in 1661 at Burford. He had six known children between 1688 and 1705 at Burford, which embraces the 1699 date we need for Hercules. There are no other Humphreys males baptising children at this time to compete for possible parentage against this. Figure 10 shows a family tree for Hercules.

Hercules is an unusual name, although there are a small number of other people called Hercules Humphreys at this time. John II had an elder brother (son of John I) called Hercules, born in 1655 at Burford. ${ }^{44}$ John III is the father of Hercules of 1712. John II is possibly the father of Hercules of 1699. So, within this family, there are three males named Hercules. There is also a strong naming pattern with females in this family. Hercules had a daughter called Phyllis born in 1739. If he is the son of John II (which I feel there is a strong case for) he had a sister called Phillis born in $1704^{45}$ and an aunt called Phillis born in $1659 .{ }^{46}$ 


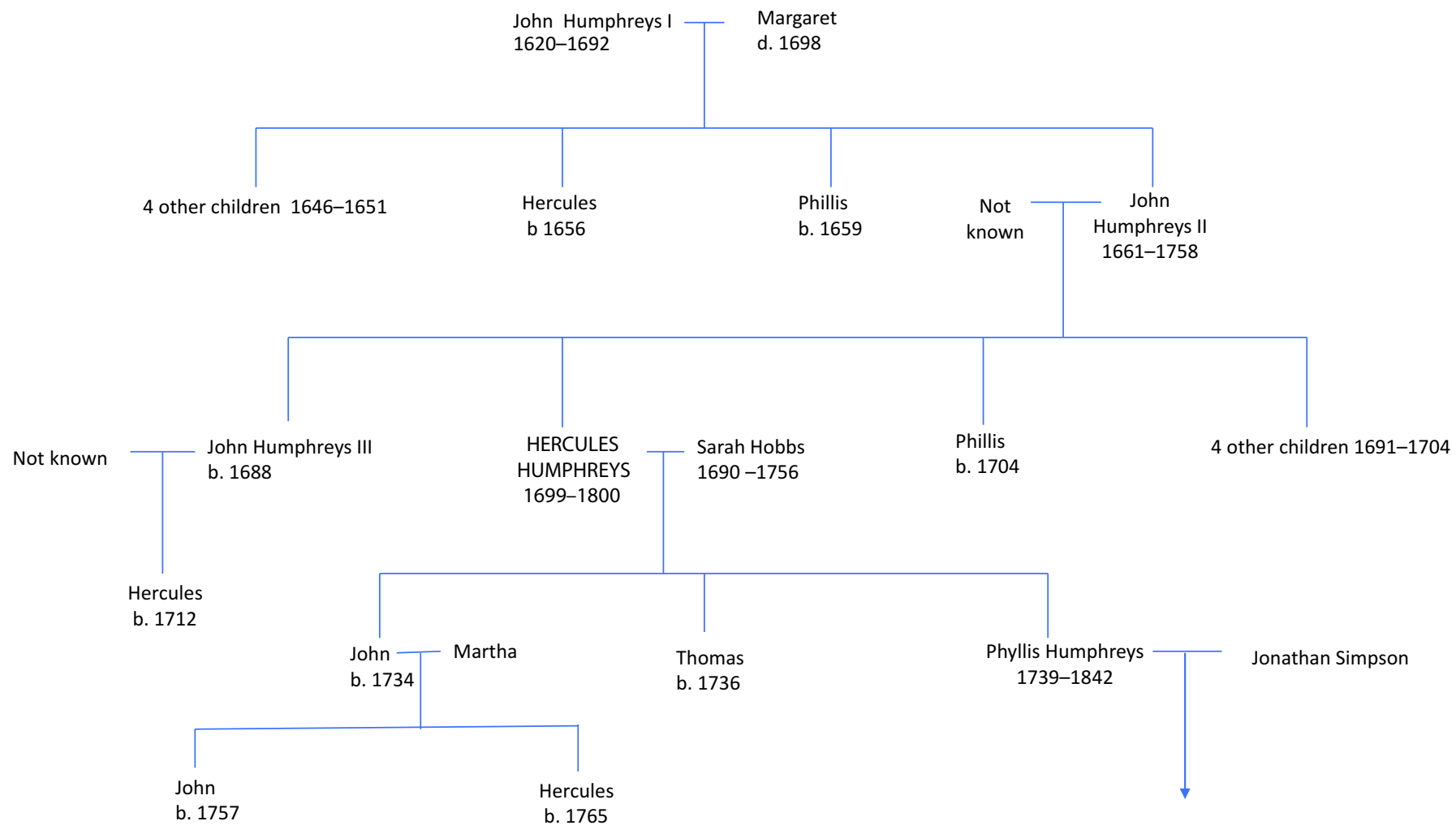

Figure 10. Family tree.

We do know that the father of Hercules was said to have lived to be 107 years old, according to Thomas Symonds. ${ }^{47}$ The Eynsham Record $^{48}$ suggests that the burial record for a Hercules Humphreys at Eynsham on 24 May 1765 could be the father. However, the overseers' accounts at Eynsham $^{49}$ show this burial to be a son of 'Humphrys' instead. The records note 'June 11765 Humphry's boy dead 15/' and 'paid for Humphry's boys coffin $6 /$ ' and 'paid for the clerk burial ditto $2 / 1$ '. The records do not specify which Humphreys was the father; it is likely that he was the son of one of Hercules' sons, John born in 1734, or Thomas born in 1736. John is the likelier candidate as he did marry and have a child, also called John, in 1757, whereas there are no subsequent records for Thomas. However, there is no baptism record at Eynsham, Burford or St Martins, Oxford, for this younger Hercules, to be sure of his parentage.

There are no other likely burials at Eynsham for the father of Hercules. At Burford, however, where we know Hercules came from (and that he may have been the son of John II), there is a burial on 13 March 1758 of a John Humphreys. ${ }^{50}$ If this is the John born in 1661 , this would make him 97 years old, which is around 10 years short of the verbal evidence of 107 given to Symonds, but still a great age. The only problem with this is that the Burford registers subsequent to this (from April 1758 onwards) record a smallpox epidemic as the cause of death for a considerable number of people for several months. There was a family of another John Humphreys at this time at Burford, who lost several children to the epidemic as well as his wife. There is no other record of a John dying unless this March 1758 record is the father of that family and he died first (before the records were recording the cause 'smallpox'). However, the record for the wife of this John on 13 May 1758 says 'Mary wife of Jn Humphreys'. ${ }^{51}$ She is not listed as the widow of John, which possibly suggests he was still living. If this is accurate, it could indicate that the father of this tragic family survived, and that the burial in March 1758 was of the much older John II, the possible father of Hercules, although this cannot be proven. However, if this is so, there is the intriguing possibility that the father of John II, John I who died in 1692 and was described as 'an aged man', ${ }^{52}$ and who may have been born at Brize Norton in $1620,{ }^{53}$ lived to be 72 . This is another great age for the times, suggesting three generations of longevity in the family.

\section{Other men named Hercules Humphreys}

There were others named Hercules Humphreys who may or may not be related. They all lived within a close geographical area straddling the counties of Oxfordshire, Gloucestershire and Wiltshire. They were useful to research in case some connection to, or hard evidence about, Hercules of 1699 was discovered. It was a possibility that there was another Hercules out there who was born and/or baptised in 1699. This did not prove to be the case, but helped with eliminating the possibilities. 
There was a 'Hercules Humphries of Highworth widr' who married at Burford on 14 January $1695^{54}$ 'by lic Elinor Moore of Lechlade'. There was a Hercules Humphreys at Highworth, Wiltshire (a glazier) who was married to Hannah and had five children. Hannah died and was buried at Highworth on 10 December $1694 .^{55}$ This is very likely an extremely quick remarriage by this Hercules who is recorded as a widower at the time. It was not uncommon for quick remarriages where there were children to be looked after. However, there were no further children of Hercules and Elinor baptised at Burford, Highworth or Lechlade, Gloucestershire. Hercules was buried at Highworth on 9 February $1709 .{ }^{56}$ This Hercules may be the Hercules born in 1655 at Burford, but there is no proof - only the circumstantial connection with Burford, and that there are no earlier generations of Humphreys at Highworth, Gloucestershire.

At nearby Sherbourne there was an active family of Humphreys. Here there was another Hercules Humphreys who was buried at Sherbourne, Gloucestershire on 6 February 1693, according to the International Genealogical Index, which might have provided a lead by following the Christian name. However, this is not borne out by the burial registers for Sherbourne as there is no record of this event. There was also a marriage at Burford on 28 April 1694 of 'John Humfries of Sherburne to Sarah Richmond of Byberry by lic ${ }^{157}$; it is possible that this John could be the father of either Hercules of 1699 or 1712 . However, there is nothing subsequent to the marriage in 1694 at Burford, Sherbourne or Bibury, and no other males named Hercules in the period searched, 1680-1720.

\section{Hercules and his children}

The number of children and descendants is a feature of the popular interest in great age. It perhaps confirms a potency which testified to long life.

Hercules probably moved to Eynsham from Burford sometime in the early 1720 s, having lived there 'nearly four score-years' by his death in $1800 .^{58}$ He married Sarah Hobbs at Eynsham on 1 April $1733 .^{59}$ Sarah was thirty-six when she married Hercules. She was buried on 12 December 1756 at Eynsham, aged fifty-nine. ${ }^{60}$ Given her age in respect of child-bearing, it may be that they only had the three children recorded in the baptism registers: John, baptised on 15 April $1734^{61}$ (named after Hercules' putative father); Thomas, baptised on 18 April $1736^{62}$ (named after Sarah's father); and Phillis, baptised on 11 March 1738 (named after Hercules' putative aunt and sister). ${ }^{63}$ John is likely to be the child who is mentioned in the Gentleman's Magazine ${ }^{64}$ as being the eldest (surviving) at seventy-three; although he was in fact only sixty-six. Phillis is the daughter whom Symonds ${ }^{65}$ spoke to and who was present at the last rites, who claimed to be seventy-one, but in fact was sixty-one.

The other children of Hercules, mentioned variously, must be grandchildren or even great-grandchildren: 'the youngest under 10 years of age', 66 'the youngest only 7 years old', 67 'a younger daughter was present aged $13^{\prime}{ }^{68}$ His daughter Phillis was married to Jonathan Simpson at Eynsham on 9 October 1759: 'Jonathan Simpson of Witney and Phillis Humphries by lic'. ${ }^{69}$ They had three known sons: Thomas in $1760^{70}$; John in $1763^{71}$ (both baptised at Witney); and the third, William, baptised at Filkins in $1766 .^{72}$ Their son John Simpson married Sarah Richens in $1791^{73}$ and had several children at Witney: Mary, born in 1792; Elizabeth, born in 1793; Jane, born in 1795; William, born in 1797; and Ann, born in 1800. These children, being grandchildren of Hercules, may account for one or more of the cited 'children' of Hercules.

Of Hercules' two sons (John, born in $1834^{74}$ and Thomas, born in $1736^{75}$ ), there are no records for Thomas subsequent to his baptism on 18 April 1736. John, however, did marry. There is no record of this, but there is a burial record at Eynsham on 10 December 1753 for 'Martha wife of John Humphrys'. ${ }^{76}$ Then, on 3 April 1757, there is a baptism record for 'John son of John and Mary Humphrys ${ }^{177}$ which suggests he remarried, and then had a son called Hercules baptised on 24 May $1765,{ }^{78}$ but there are no subsequent traceable baptisms of children for either of these to track further children born to them and lead to the time period needed for the young children of Hercules in 1800.

There is a burial record at Eynsham for a 'John Humphries age 22' at Eynsham on 18 October 1814 which would have him born in 1792 (although there is no record of this at Eynsham); this makes him the right age to be one of the 'children' but we do not know if he is even related..$^{79}$ There is also a family of William and Elizabeth Humphreys who had three children by 1800: Mary, born in 1796; Ann, born in 1798; and Samuel, born in February 1800. Again, we do not know if or how they may be related to Hercules; it is possible that William is the son of Hercules' son John.

Hercules himself remarried in 1759: 'Hercules Humphreys widower of Oxford, St. Martin, Cordwainer, and Mary Buckingham, widow of Eynsham, 11 August 1759 at Oxford, St. Martin' ${ }^{80}$ Mary is possibly the recently widowed wife of Philip Buckingham who died in 1757 and was buried at Eynsham on 25 September. ${ }^{81}$ Philip and Mary Buckingham had one known child, Thomas, born in 1745 at Eynsham; he may have still been living at the time of the marriage to Hercules as there is no record of his burial at Eynsham prior to that. It is important to note that Hercules was clearly upwardly mobile, to be living in the centre of Oxford in the upmarket parish of St Martin's. St Martin's church was an 
important place: it was the church used by the corporation for ceremonial and religious events, and where many mayors of Oxford were buried. It was demolished in 1820 as it was unsafe, rebuilt by 1822, and demolished again in 1896 as part of a road-widening scheme. Only the thirteenth-century west tower remains today.

Hercules' second marriage appears not to have been a success. Jackson's Oxford Journal of 16 May 1761 announced that:

\begin{abstract}
Whereas Mary the wife of Hercules Humphreys of the Parish of Ensham, Cordwainer, did on the 4th of this instant May, elope from her said husband and is not yet returned. These are to give publick Notice, that the said Hercules Humphreys will not pay any Debts his said wife may contract during the continuance of her Elopement; And if any Persons shall entertain or permit his said wife to cohabit with them, such Person or Persons will be prosecuted for so doing by me. HERCULES HUMPHRYS. ${ }^{22}$
\end{abstract}

Mary Humphreys seems to have left him after he assaulted her. Hercules was summoned to the Easter Quarter Sessions of 1761 to answer a complaint that he and two other men assaulted her: 'Hercules Humphries, shoemaker, James Bowerman, slater, and James Webb, joiner, all of Ensham were presented at court for an assault on his wife Mary on May $4^{\text {th }} 1761^{\prime} .^{83}$ Hercules pleaded not guilty and was sent for trial at the Trinity Sessions. They were bound over on their own recognisance in the sum of $£ 10$ each. Hercules was fined 1/- at the Trinity Sessions. ${ }^{84}$

In the same month, only one week after Mary had been attacked by and fled from her husband, a child was baptised at Eynsham. The entry in the baptism register reads: '1761, May 11th, Richard Humphreys, son of Mary'. ${ }^{85}$ By this time, it had been normal for some forty years for the Eynsham baptismal records to give both parents' names; this entry does not. Given the events of May 1761, it is clear that Mary bore a child; that she fled having been assaulted by her husband and others; but that she left Oxford, and had her child baptised at Eynsham without declaring the father's name. It is possible that Hercules was not the father, and that he refused to acknowledge the child. The child may well have died in infancy as there is a burial record for 22 November 1761 of a Richard Humphreys at Eynsham. ${ }^{86}$ (There is also a later burial record for a Richard Humphries on 8 November 1770 at Eynsham which may or may not be the same child, or could be a son of John Humphries, Hercules' son but not recorded in the baptism records.)

It would appear that, on the matter of fertility which was of great interest to the public, Hercules was not as desirably prolific as some of the other centenarians were presented to be. The testimonies refer to 'children' which probably embraces actual children, grandchildren and great-grandchildren. It is not possible to be certain, but all known descendants at the time of Hercules' death (if they were all still living) would suggest some seventeen 'children'. Perhaps the testimonies have emphasised another form of potency in age range, with the eldest at seventy-three and the youngest at seven years: if he was fathering children in his nineties, this suggested continued potency and may have seemed to have accounted for his long life.

\title{
Conclusion
}

The portrait of Hercules Humphreys at first seemed to be an isolated picture which was of interest and presented research challenges. The process of trying to verify its claim that Hercules was aged 101 led to an understanding of its context which has shown it to be more than a lucky find. Instead it was part of a popular and topical genre at the time. There was an on-going fascination among people, the press, collectors, antiquaries, alchemists, and people looking for secrets to a long life.

There are, of course, doubts about these claims. Petersen and Jeaune refer to the investigative work of Thoms, where he has concluded that the 'burden of proof in these cases should rest with those who put forward the age claims, rather than with those who dared disbelieve the amazing age-claims' ${ }^{87}$ In terms of whether the claim was true in this case, which was the main driver for this research, it is likely that it was. The evidence of Symonds, who says he saw a baptism record and date, is persuasive because it is not a birthdate which he could easily have been given. Even though the record does not exist today, Symonds as an antiquary would not be likely to fabricate his evidence. It is not in legal terms 'beyond reasonable doubt', but may pass the test of 'on the balance of probabilities'. To some extent, it is the proof on the part of the claimant to great age that Thoms required. I can think of no reason to doubt Symonds' testimony. I can also see, however, that Hercules could have borrowed memories from his older wife to back up his claim to great age, in the same way as the critique by Thoms suggests some of these extraordinary people may have done.

Whatever the truth, the popular interest in people of supposed great age generated portraits of people such as Hercules. The people in these portrait collections tend to be of the lower and middling sorts of society, rather than the wealthy and powerful. This enables us to see images of people who, but for their age, would not have bequeathed their image to posterity and to historians. 


\section{Citation information}

Cite this article as: Cooper, Trevor J. (2019) Hercules Humphreys: celebrity centenarian? Journal of Genealogy and Family History. 3(1). http://dx.doi.org/10.24240/23992964.2019. 1234523

\section{References}

1. Marriage announcements. (1761) Jackson's Oxford Journal, 16 May. HUMPHREYS, Hercules and BUCKINGHAM, Mary. p. 2c. www.findmypast.co.uk.

2. Oldfield, W. J. Calendar of Oxon Quarter Sessions 1687-1830. Vols 1-XI. RI 1761 E9. Oxfordshire Record Office.

3. Baggs, A. P., Colvin, C., Colvin, H. M., Cooper, J., Day, C. J., Selwyn, N. and Tomkinson, A. (1983) 'Wootton hundred'. In: Crossley, A. ed. A history of the county of Oxford. Vol. 11, Wootton Hundred (Northern Part). London: Victoria County History. pp. 1-5. http://www.british-history.ac.uk/vch/oxon/vol11/pp1-5.

4. Jackson's Oxford Journal. (1759) To be lett. Jackson's Oxford Journal. 22 December p. 3c. www.findmypast.co.uk.

5. Jones, E. L. (1967) Agriculture and economic growth in England 1650-1815. pp. 31-32.

6. Jones, Eric L. (2010) Documents with regard to bonds and loans to Hercules Humphreys. Email to Trevor Cooper.

7. Bodleian Library. Collection Level Description: Topographical Collections of Henry Hinton and James Hunt. http://www.bodley.ox.ac.uk/dept/scwmss/wmss/online/ 1500-1900/hinton/hinton.html.

8. Wright, L. and Atkins, B. (1993) Hercules Humphries, 1699-1800. Eynsham Record, 10. p. 33.

9. Rylands, W. H. and Songhurst, W.J., eds. (1915) Ars Quatour Coronatum: The Transactions of the Quatour Coronati Lodge, Number 2076. The Collectanea of the Rev Daniel Lyons, FRS, FSA. pp. 41-44.

10. Rylands, W. H. and Songhurst, W.J., eds. (1915) Ars Quatour Coronatum: The Transactions of the Quatour Coronati Lodge, Number 2076. The Collectanea of the Rev Daniel Lyons, FRS, FSA. p. 41

11. Philalethes, Eugenius (1722) Long livers: a curious history of such persons of both sexes who have liv'd several ages, and grown young again: with the rare secret of rejuvenescency of Arnoldus de Villa Nova. London: J. Holland \& L. Stokoe. https:// archive.org/details/b3051244x/page/n10

12. Psalms 90:10. Holy Bible: King James Version.

13. Genesis 5:21-27. Holy Bible: King James Version.

14. Rylands, W. H. and Songhurst, W. J., eds. (1915) Ars Quatour Coronatum: The Transactions of the Quatour Coronati Lodge, Number 2076. The Collectanea of the Rev Daniel Lyons, FRS, FSA.

15. Rylands, W. H. and Songhurst, W. J., eds. (1915) Ars Quatour Coronatum: The Transactions of the Quatour Coronati Lodge, Number 2076. The Collectanea of the Rev Daniel Lyons, FRS, FSA. p. 42.

16. Rylands, W. H. and Songhurst, W. J., eds. (1915) Ars Quatour Coronatum: The Transactions of the Quatour Coronati Lodge, Number 2076. The Collectanea of the Rev Daniel Lyons, FRS, FSA. p. 43

17. Rylands, W. H. and Songhurst, W. J., eds. (1915) Ars Quatour Coronatum: The Transactions of the Quatour Coronati Lodge, Number 2076. The Collectanea of the Rev Daniel Lyons, FRS, FSA. p. 43.

18. Petersen, L-L. B and Jeune, B. (2003) Age validation of centenarians in the Luxdorph Gallery. Copenhagen: Max-Planck Gesellschaft. p. 2.

19. Thoms, W. J. (1873) Human longevity: its fact and its fictions. London: John Murray. https://archive.org/details/humanlongevityi00thomgoog/page/n9.

20. Petersen, L-L. B and Jeune, B. (2003) Age validation of centenarians in the Luxdorph Gallery. Copenhagen: Max-Planck Gesellschaft. pp. 4-6.

21. Rylands, W. H. and Songhurst, W. J., eds. (1915) Ars Quatour Coronatum: The Transactions of the Quatour Coronati Lodge, Number 2076. The Collectanea of the Rev Daniel Lyons, FRS, FSA. p. 42.

22. Taylor, John (1635) The old, old, very old man: or, the age and long life of Thomas Par, the son of John Parr of Winnington. London: Henry Goffon. https://archive.org/ details/oldoldveryoldman00tayliala/page/n8

23. Thoms, W. J. (1873) Human longevity: its fact and its fictions. London: John Murray. pp. 85-94. https://archive.org/details/humanlongevityi00thomgoog/page/n9.

24. Dean and Chapter of Westminster Abbey. Thomas Parr. https://www.westminsterabbey.org/abbey-commemorations/commemorations/thomas-parr\#i13742

25. Thomas, Keith. (2017) 'Parr, Thomas [called Old Parr] (d. 1635), supposed centenarian'. In: Oxford Dictionary of National Biography. Oxford: Oxford University Press. https://www.oxforddnb.com/view/10.1093/ref:odnb/9780198614128.001.0001/ odnb-9780198614128-e-21403.
26. Rubinstein, W.; Jolles, M. A. and Rubinstein, H. L., ed. (2011) The Palgrave Dictionary of Anglo-Jewish History. London: Palgrave Macmillan. p. 627.

27. Cohen-Grossman, G. (1996) The Skirball Museum collections and inaugural exhibition. p. 61. Los Angeles: University of California.

28. Clarke, G. R. (1830). The History and description of the town and borough of Ipswich London: Hurst, Chance \& Co. London. p. 320

29. Brown, M. (1992) An Ipswich worthy portrayed by John Constable. Jewish Historical Studies. 33. pp. 137-139. https://jhse.org/articles/an-ipswich-worthy-portrayed-byjohn-constable/.

30. J. A. (1808) Instances of longevity: Lyons and Old Ingall. Letter to the Editor. The Monthly Magazine or British Register. 25. p. 221. https://babel.hathitrust.org/cgi/pt? id =chi.79289142\&view $=1$ up\&seq $=4$

31. Overseers' Accounts for Eynsham. Bodleian Library, Oxford. MS DD Par 615. p. 8.

32. Burials (PR) England. Eynsham, Oxfordshire. 22 September 1800. HUMPHREYS, Hercules. Oxfordshire Record Office.

33. Rylands, W. H. and Songhurst, W. J., eds. (1915) Ars Quatour Coronatum: The Transactions of the Quatour Coronati Lodge, Number 2076. The Collectanea of the Rev Daniel Lyons, FRS, FSA. p. 43.

34. Context-setting citation accompanying the portrait of Hercules. R. Slatter, printer MS DON C90. folio 427. Bodleian Library, Oxford.

35. Context-setting citation accompanying the portrait of Hercules. R. Slatter, printer. MS DON C90. folio 427. Bodleian Library, Oxford.

36. Obituaries. (1800) Gentleman's Magazine. HUMPHREYS, Hercules. p. 1006b. https:// babel.hathitrust.org/cgi/pt?id=mdp.39015030606480\&view=1 up\&seq=430.

37. Obituaries. (1800) Hull Packet. 7 October. HUMPHREYS, Hercules. p. 3b.

38. Baggs, A. P., Blair, W. J. Chance, E., Colvin, C., Cooper, J., Day, C. J., Selwyn, N. and Townley, S. C. (1990) 'Eynsham: churches'. In: Crossley, A. and Elrington, C. R., ed. A history of the county of Oxford. Vol. 12, Wootton Hundred (South) including Woodstock. London: Victoria County History. pp. 147-152. http://www.british-his tory.ac.uk/vch/oxon/vol12/pp147-152.

39. Burials (PR) England. Eynsham, Oxfordshire. 22 September 1800. HUMPHREYS, Hercules. Oxfordshire Record Office.

40. Thomas Symonds' Commonplace Book. Bodleian MS Don. d. 180, folio 4. Bodleian Library, Oxford.

41. Cooper, T. J. (2017) Bricks in the wall. Journal of Genealogy and Family History. 1(1)

42. Baptisms (PR) England. Eynsham, Oxfordshire. 1 April 1697. HOBBS, Sarah. Oxfordshire Record Office.

43. Context-setting citation accompanying the portrait of Hercules. R. Slatter, printer MS DON C90. folio 427. Bodleian Library, Oxford.

44. Baptisms (PR) England. Burford, Oxfordshire. 18 May 1655. HUMPHREYS, Hercules. Oxfordshire Record Office.

45. Baptisms (PR) England. Burford, Oxfordshire. 11 May 1704. HUMPHREYS, Phillis. Oxfordshire Record Office.

46. Baptisms (PR) England. Burford, Oxfordshire. 20 February 1659. HUMPHREYS, Phillis Oxfordshire Record Office.

47. Thomas Symonds' Commonplace Book. Bodleian MS Don. d. 180, folio 4. Bodleian Library, Oxford

48. Wright, L. and Atkins, B. (1993) Hercules Humphries, 1699-1800. Eynsham Record, 10. p. 33.

49. Overseers' Accounts for Eynsham. Bodleian Library, Oxford. MS DD Par 615, p. 8.

50. Burials (PR) England. Burford, Oxfordshire. 13 March 1754. HUMPHREYS, John Oxfordshire Record Office.

51. Burials (PR) England. Burford, Oxfordshire. 13 May 1758. HUMPHREYS, Mary. Oxfordshire Record Office.

52. Burials (PR) England. Burford, Oxfordshire. 11 December 1692. HUMPHREYS, John. Oxfordshire Record Office.

53. Baptisms (PR) England. Brize Norton, Oxfordshire. 30 December 1620. HUMPREYS, John. Oxfordshire Record Office.

54. Marriages (PR) England. Burford, Oxfordshire. 14 January 1695. HUMPHRIES, Hercules and MOORE, Elinor. Oxfordshire Record Office.

55. Burials (PR) England. Highworth, Wiltshire. 10 December 1694. HUMPHRIES, Hannah. Wiltshire Record Office.

56. Burials (PR) England. Highworth, Wiltshire. 9 February 1709. HUMPHRIES, Hercules Gloucestershire Record office.

57. Marriages (PR) England. Burford, Oxfordshire. 28 April 1694. HUMFRIES, John and RICHMOND, Sarah. Oxfordshire Record Office.

58. Context-setting citation accompanying the portrait of Hercules. R. Slatter, printer. MS DON C90. folio 427. Bodleian Library, Oxford. 
59. Marriages (PR) England. Eynsham, Oxfordshire. 1 April 1733. HUMPHREYS, Hercules and HOBBS, Sarah. Oxfordshire Record Office.

60. Burials (PR) England. Eynsham, Oxfordshire. 12 December 1756. HUMPHREYS, Sarah. Oxfordshire Record Office.

61. Baptisms (PR) England. Eynsham, Oxfordshire. 15 April 1734. HUMPHREYS, John. Oxfordshire Record Office.

62. Baptisms (PR) England. Eynsham, Oxfordshire. 18 April 1736. HUMPHREYS, Thomas. Oxfordshire Record Office.

63. Baptisms (PR) England. Eynsham, Oxfordshire. 11 March 1738. HUMPHREYS, Phillis. Oxfordshire Record Office.

64. Obituaries. (1800) Gentleman's Magazine. HUMPHREYS, Hercules. p. 1006b. https:// babel.hathitrust.org/cgi/pt?id=mdp.39015030606480\&view=1 up\&seq=430.

65. Thomas Symonds' Commonplace Book. Bodleian MS Don. d. 180, folio 4. Bodleian Library, Oxford.

66. Context-setting citation accompanying the portrait of Hercules. R. Slatter, printer MS DON C90. folio 427. Bodleian Library, Oxford.

67. Obituaries. (1800) Gentleman's Magazine. HUMPHREYS, Hercules. p. 1006b. https:// babel.hathitrust.org/cgi/pt?id=mdp.39015030606480\&view=1 up\&seq=430.

68. Thomas Symonds' Commonplace Book. Bodleian MS Don. d. 180, folio 4. Bodleian Library, Oxford.

69. Marriages (PR) England. Eynsham, Oxfordshire. 9 Oct 1759. SIMPSON, Jonathan and HUMPHRIES, Phillis. Oxfordshire Record Office.

70. Baptisms (PR) England. Witney, Oxfordshire. 5 July 1760. SIMPSON, Thomas Oxfordshire Record Office.

71. Baptisms (PR) England. Witney, Oxfordshire. 11 September 1763. SIMPSON John. Oxfordshire Record Office

72. Baptisms (PR) England. Filkins, Oxfordshire. 2 February 1766. SIMPSON, William. Oxfordshire Record Office.

73. Marriages (PR) England. Bradwell, Oxfordshire. 1 August 1791. SIMPSON, John and RICHENS, Sarah. Oxfordshire Record Office.
74. Baptisms (PR) England. Eynsham, Oxfordshire. 15 April 1734. HUMPHRIES, John Oxfordshire Record Office.

75. Baptisms (PR) England. Eynsham, Oxfordshire. 18 April 1736. HUMPHRIES, Thomas. Oxfordshire Record Office.

76. Burials (PR) England. Eynsham, Oxfordshire. 10 December 1753. HUMFRYS, Martha Oxfordshire Record Office.

77. Baptisms (PR) England. Eynsham, Oxfordshire. 3 April 1757. HUMPHRYS, John Oxfordshire Record Office.

78. Baptisms (PR) England. Eynsham, Oxfordshire. 24 May 1765. HUMPHRYS, Hercules. Oxfordshire Record Office.

79. Burials (PR) England. Eynsham, Oxfordshire. 18 October 1814. HUMPHRIES, John. Oxfordshire Record Office.

80. Marriages (PR) England. St. Martin, Oxford. 11 August 1759. HUMPHREYS, Hercules and BUCKINGHAM, Mary. Index of Oxford Diocese Marriage Bonds and Affidavits. Oxon Archives. MSS.Oxf.Dioc.papers d. 22-97 \& CD Parish Registers for St Martin's. Oxfordshire Family History Society. https://www.whipple.org/oxford/diocesan_mar riage_bonds.html

81. Burials (PR) England. Eynsham, Oxfordshire. 25 September 1759. BUCKINGHAM, Phillip. Oxfordshire Record Office.

82. Announcements. (1761). Jackson's Oxford Journal. 22 December. p. 2c. www.find mypast.co.uk

83. Oldfield, W. J. Calendar of Oxon Quarter Sessions 1687-1830. Vols 1-XI. RI 1761 Eg. Oxfordshire Record Office.

84. Oldfield, W. J. Calendar of Oxon Quarter Sessions 1687-1830. Vols 1-XI. Trinity 1761 Oxfordshire Record Office.

85. Baptisms (PR) England. Eynsham, Oxfordshire. 11 May 1761. Humphries, Richard. Oxfordshire Record Office.

86. Burials (PR) England. Eynsham, Oxfordshire. 26 November 1761. HUMPHRIES, Richard. Oxfordshire Record Office.

87. Petersen, L-L. B and Jeune, B. (2003) Age validation of centenarians in the Luxdorph Gallery. Copenhagen: Max-Planck Gesellschaft. p. 4.

\section{ABOUT THE AUTHOR}

Trevor J. Cooper is a former lecturer and tutor. He has contributed to the journals of the Oxfordshire, Suffolk, Cornwall and Sussex family history societies.

Email: trevor.cooper5@btopenworld.com

http://orcid.org/0000-0002-7075-9923 